\title{
穀物の国際流通：構造と特質
}

\author{
吉田十一 \\ International Marketing of Cereals : Structure and Characteristics
}

Juichi Yoshida (Shiga Prefectural University)

\begin{abstract}
Liberalizing trade in world cereals market is neither cure-all, nor perilous: Environmental merits by agricultural trade liberalization would not be so large as indicated by GATT, because the intensive application of chemicals dues not only to the government farm protection, but to other factors such as population density. Increase in food import by industrial countries would make most developing countries better off. World grain market is not so unstable in a long run. But it is necessary to improve production and marketing technology of food in the regions where cereals production would be extended in accordance with an increase in the world price. The
\end{abstract}

基本食糧である米の自給を国是としてきた日本も， 1993年の不作によって260万トンの外国産米を輸入し ようとしている。また93年末, GATTウルグアイ。 ラウンド交渉において，米の輸入義務を受け入れた。 日本の穀物流通はすべて国際市場との関わりにおいて 考えなければならなくなった。そこで，䐨物の国際流 通において特に問題之なる農業の環境に対するストレ 不負荷，国際間に抢ける貿易利益の分配，国際市場の 安定性，国際市場の競争構造などについて論点を整理 し, 穀物国際流通の新たな研究課題を明らかにする。

\section{1. 国際流通と環境保全}

GATT ウルグアイ・ラウンドの交渉過程で，農産 物貿易の自由化は自由化国の環境を改善する効果があ るといわれた。しかし，自由化の環境改善効果はあま り期待できない。まず農業の生産活動之環境との相互 規定関係から検討しよう。

農業生産と環境とは, 図1のような関係にある。F は農業，Eは環境，Gは政治システム， S は農業生産 者のような主体システムである。農業生産は農業シス テムFに扔いて行われるが，生産活動は資源の採取。

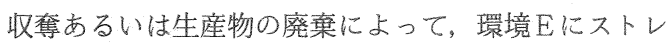

structure of world cereals market is not so competitive as an import country's private firms can enjoy the gains of free trade. The demand elasticity of price for Japanese delicious rices is not so high as to allow them to keep their superiority over imported rices.

It is suggested that the government direct intervention in improving environment would be effective. The technological aid for farm pcoduction countries would make the world grain market stable. Japan as an importer of food should keep a market power in the imperfect competitive world cereals market for a while. Farmers should compete with foreign producers by diversification of their products.

スを負荷する。環境負荷には，さらに政治システム $\mathrm{G}$ の政策，選択可能な技術( $\mathrm{T}$ ), 生産手段選択卢政策適 用を可能にする所得レベル $(\mathrm{Y})$, 農業生産者の行動様 式や政策策定に影響を与える価值観 $(V)$ あるいは世論 がかかわる。

環境 $\mathrm{E}$ に対する農業 $\mathrm{F}$ からのストレス負荷は，まず 農業システム Fに扮ける生産活動（活動レベルの拡大 生産の集約化，生産立地の集中）によって行われる。 生産活動が活発で, 化学肥料や農薬などを集約的に投 入するとその地域の環境へのストレス負荷は大きくな る。生産活動のレベルは, 生産者が経済的利益を追求 して競争的になるか, あるいは環境との調和を考慮す るか，生産者の価值体系 Vによって決まる。また具体 的な生産活動には，選択可能な技術の特性とレベル， 技術利用を可能にする所得水準Yなどが環境負荷量を 決める。選択技術 Tが環境保全型か環境負荷型か，環 境保全型技術を利用できるだけの所得があるがうかか などによって，環境へのストレス負荷量が変わる。さ らに, 農業の生産活動や環境条件の変化が外部効果を 持つ場合, 外国 (B)の生産活動之環境に影響を及ぼす。 外国加らの影響屯受ける。

環境は，また，農業生産活動政策，生産技術政策， 
、、国内における環境の規定要因

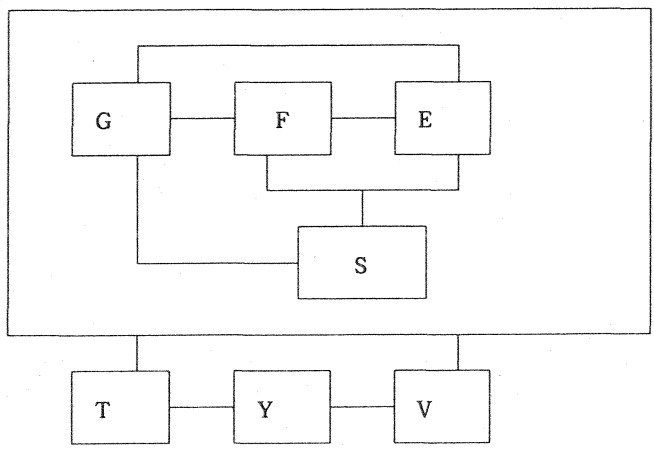

b．国際間における環境の外部作用

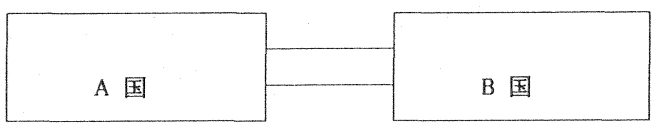

図1。農業生産之環境保全の規定要因

環境維持改善政策，貿易政策などの政策的関与からも 大きな影響を受ける ${ }^{1)}$. 生産要素投入に関する農産物 生産基準の設定, 農産物の生産調整, 生産地の制限や 配置などの生産活動抑制政策は環境負荷を軽減する。 環境保全型技術の開発・普及む環境ストレスを軽減す る。農業システムからの負荷によって環境が受ける影

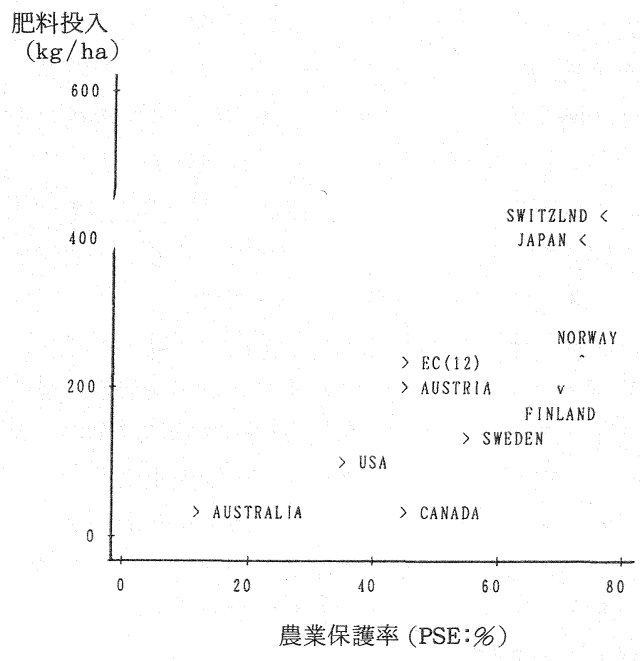

図 2 a，農業保護率 PSE と農地肥料投入
響は，環境自体のストレス負荷受容力や環境破壊に詨 する復元力などの適応力によって決まるが、環境保護。 改善政策によって適応力を高めることあできる。

反対に，農産物価格支持や生産助成は農業生産活動 を助長し，環境ストレスを高める，自由化政策が環境 保全に役立つという論処はここから出ている。すなわ ち，保護政策によって助長されている肥料・農薬など の集約的投入や集中的生産を保護の削減・撤廃によっ て是正し，環境の保全・保護を図る。環境負荷が集中 している地域から環境負荷がない地域へ，農業生産の 一部を移動させることによって，環境改善が可能であ

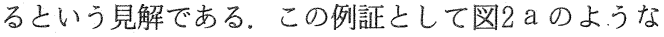
各国の農業保護費用 P S E と肥料投入量との相関図が 例示される (Parris)。本図の肥料投入量は窒素・憐 酸・カリの農地ha当たり投入成分量（kg）である。 直線回帰の決定係数は0.6492。農業保護が高くなるに つれて肥料投入が多くなっている，自由化によって保 護助成を軽減すると, 肥料や農薬投入量が滅って, 環 境負荷が軽減されるというのである。ところが，同じ 国々について，横軸に農地人口密度（ha当たり人）, 縦軸に農地ha当たり肥料投入成分量をとって図示す ると，図 $2 \mathrm{~b}$ のようになる。 土地面積当たりの肥料の 投入水準は，人口密度に依存していることがわかる。 決定係数は 0.7355 である。したがって，あし要素投入 が農業保護以外の要因により強く依存しているとすれ ば, 農産物貿易自由化の環境保全効果はあまり期待で きない。

さらに，自由化を契機に生産者がコスト競争を指向

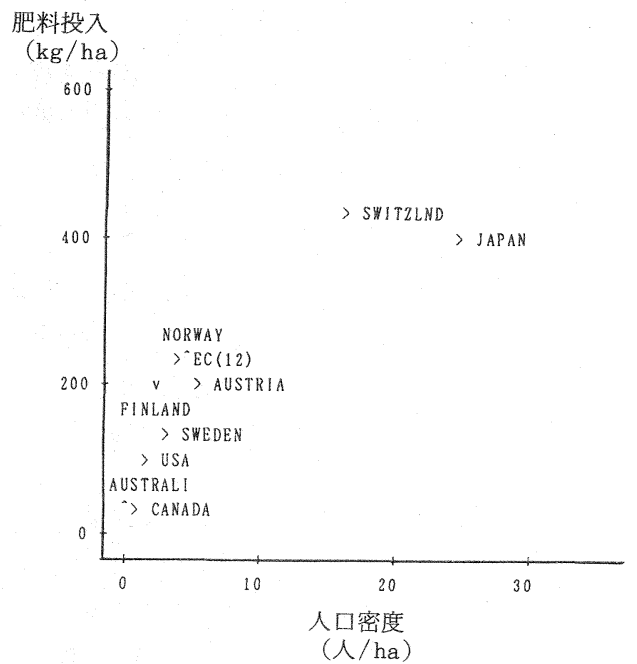

図 2 b。農地面積当たり人口密度と農地肥料投入 
した場合，環境負荷のかかっていた国むかかっていな かった国も，生産要素投入が增加し，環境悪化がさら に進行する危険性も考えられる。また国際競争に対応 して農産物生産基準政策が緩和の方向へ向かうと, 環 境負荷はさらに強化される. 自由化によって農産物市 場価格が上昇した国では，価格上昇が投入増加や資源 収奪を助長し, 環境をより悪化させることも考えられ る.あるいは，ある国が緩和された投入基準によって 生産した農産物を輸出する場合, 輸入国において環境 負荷への制裁関税が設定される可能性むある。Antle は, 農業生産物と環境サービスとの変形フロンティア が, 自由化による所得拡大によって, 環境サービス指 向型へダイナミックに变化することを期待している。

しかし, 環境保全を考慮した生産技術政策と環境保全 政策抜きで環境保全を実現することは困難である。自 由化の環境保全効果は一義的には決められないし, そ の効果ああまり期待できない.

\section{2. 国際流通亡経済厚生}

次に, 先進工業国が, 輸入制限や輸出補助などの農 業保護を撤廃して, 国際市場からの穀物輸入を拡大す ることは開発途上国の穀物価格を上昇させ，途上国国 民を不利化するという主張がある。そういう事態はす べての途上国において起こるわけではない。

\section{(1) 穀物生産の優位性}

農業保護撤廃が穀物価格や経済厚生に及ぼす影響の 大きさは，各国の穀物生産における比較優位性，その 国の貿易政策，そして所得水準によって決まる。

保護撤廃工業国は, 国産穀物価格より安い価格で外 国産穀物を輸入して, 経済厚生が増加する. 穀物生産 で比較優位に立つ輸出国は，下表のように，工業国が 大量に穀物を輸入するので, 穀物輸出価格が上昇し,

\begin{tabular}{cc}
\hline \hline 穀物生産の優位性 & 価格, 余剩の変化 \\
\hline 優位 $/$ 輪出国 & 上昇, 増加 \\
中位 $/$ 輸出国 & 上昇, 増加 \\
劣位 $/$ 自給国 & 上昇, 減少 $?$ \\
劣位 $/$ 輸入国 & 下落, 減少 \\
\hline
\end{tabular}

生産拡大によって生産者余剩が増加し, 経済厚生が増 加する。穀物生産の優位性が中位で, 少し輸出するか, ほとんど自給自足状態にある国においてす, 穀物輸出 価格上昇によって, 経済厚生が増加しよう。

比較劣位にあるか全く穀物生産をしない国では, 穀 物価格の上昇による消費者余剩の減少によって, 経済 厚生が減少するかむしれない，消費者余剩の減少を相 殺して, より大きな経済厚生が実現するには, 大幅な 価格上昇によって，生産者余剩が著しく增加すること である。この場合，供給の価格弾力性が非常に高くな ければならない，ただし，国際市場における穀物価格 の上昇が比較劣位にある国の豰物生産の技術革新を誘 発し，供給曲線を右シフトさせれば，こうした国の経 済余剩も增加する。

\section{(2) 貿易政策}

工業国の農業保護撤廃による有利化効果は，各国の 貿易政策によっても異なる。まず輸入制限国および輸 出補助国は, 安い価格で外国産穀物を輸入して, 保護 撤廃前より消費者余剩を增加させる。輸出補助国では, さらに国際価格上昇分だけ補助金を減額できるので, 政府負担が減る。しかし，国内の穀物価格を国際価格 より低目に設定していた国では，国内価格を一定に保 とうとすると, 国際市場価格の上昇によって状況が変 わる。輸入助成国では，国産穀物の供給価格弾性が大 きくないと，助成金支出が增加して政府負担が增える。 輸出課税によって穀物輸出を制限していた国では，重 量課税の場合，国際市場における穀物価格の上昇によっ て輸出量が増加する。 そこで, 一定の国内消費量を確 保するために関税率を上げると, 輸出関税収入の增加 分だけ，経済厚生が増加する。

農業保護撤廃がその他の国の貿易政策の緩和あるい は撤廃を誘発させて, 穀物の国際流通を拡大させるな ら, 多くの国の経済厚生が増大する。ただし，輸出制 限国の穀物の輸出価格弾性が高い場合, 消費者余剩と 関税収入の減少分とを生産者余剩の増加分で相殺でき ない，経済厚生はむしろ減少する。この減少分は外貨 収入増によってあ相殺できないキースがある。例えば, パキスタンの Basmati riceに対する輸出価格弾性は

\begin{tabular}{c|c|c}
\hline \hline 貿易政策 & 工業国の保護撤廃による効果 & 自由貿易の効果 \\
\hline 輸入制限国 & 国内価格低下, 補助額減, 厚生増 & 補助額減, 厚生増 \\
輸出補助国 & 国内価格低下, 補助額減, 厚生増 & 補助額減, 厚生増 \\
輸入助成国 & 輸入価格上昇, 助成額増, 厚生減 & 助成額減, 厚生増 \\
輸出制限国 & 輸出価格上昇, 徵税額増, 厚生増 & 徵税額減, 厚生増/減 \\
\hline
\end{tabular}

注 : 輸入助成国は一定量を輸入し, 輸出制限国は一定量を輸出するとする. 
-1.95 で，輸出税撤廃は税収が減少し，純便益が減少 する(Chishti)，なお，保護撤廃による国際価格の 上昇に対して，輸入助成国が助成負担額を増加させな い場合，消費者余剩は減少するが，価格上昇による国 内穀物生産の拡大が生産者余剩を増加して，消費者余 剩減少分の一部あるいは全部を相殺することが可能と なる。

\section{（3）所得格差と需要の価格弾性}

農業保護撤廃の影響は, 国家間の所得格差之穀物需 要価格弾性とによってる異なる2).

工業国の農業生産保護撤廃は, 輸入豰物価格の低下 によって消費者余剩を増大する。しかし，低所得輸入 国では，国際市場価格の上昇によって，生産者余剩は 增加するが消費者余剩の隇少をカバーできなくなる。

例光ば,Anderson 等は，バングラデッシュやエジ プトは自由化の利益配分に与らないと予測している。

\section{3。国際市場の安定性}

国際市場に依存して穀物を安定的に供給できるか。

国際市場は各国市場の結合によって形成される。市 場結合には，相互に開放的になるか，必要時にのみ取 引するか，全く交易せずに独自の自給自足市場を形成 するか，3つのタイプがある。図 3 の A，B，Cの国は 相互に穀物取引をして国際市場Mを形成している。 D 国は，D国が必要なときのみ国際市場で穀物取引をす る。E国は完全な封鎖市場となっている。各国の国内 市場は，条件変化によって衝撃を受けると，何らかの 方法で調整する。例えばA国は，国内市場で発生した 衝撃を国際市場に伝達し，B・C国がその衝撃を吸収 する，衝擊が反詨の性格を持っていれば，相互に相殺

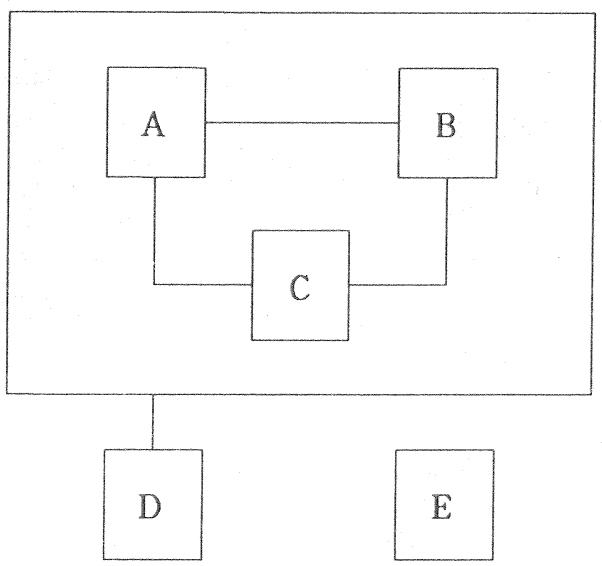

図 3、国際市場の形成：結合タイプ
される。緊急時のみ国際市場を利用するD国は，国際 市場に衝撃を伝達して, 自国市場を安定化する。国際 市場の安定性は、こうした条件変化の衝擊の伝達を吸 収・調整することによって保たれる。

\section{(1) 市場の攪乱と調整}

個別市場 : 個別市場の攪乱要因は，短期的には，自 然条件（気象の変化，病虫害の発生，地殼の変動）, 社会条件 (争議や紛争の発生), 経済条件 (景気・所 得変動，補完・代替物の出現や生産変動）などである。 中期的には，技術革新，消費者队国民の価值観の变化 なぞが市場を攪乱する。これらによって，個別市場の 需給関係がアンバランスになり，市場が不安定になる。 しかし，個別市場の変動がどの程度になるかは，それ ぞれの条件変化の程度によるとともに，条件変化が発 生した国の市場の需給特性と市場の衝撃調整力とによ る。国民の所得水準が高いと，穀物需要価格弾性が小 さくなり，穀物価格を不安定化する。しかし，国内に おける穀物生産が分散的であったり，变化に対する技 術的適応力を持っていれば, 豰物供給の価格弾力性が 大きくなり，変動は抑制される。十分な備蓄を持って いても国内市場の変動を抑制できる。

国際市場 : 国際市場の攪乱は，ある国が国内市場の 変動を国際市場に波及させることによって起こる。国 際市場の変動の大きさは，それぞれの国が持ち込む変 動の大きさと国際市場の特性とによって決まる。国際 市場の特性は，市場の統合度，需給構造，在庫規模な どによって形成される，国際市場に結合する国が多く なって市場統合度が深まれば，個別市場からの衝撃を 吸収する力が高まる。相反する条件変化は相互に相殺 できる，国際市場に対する穀物供給国が安定的な供給 国であるか，あるいは穀物供給構造が分散的であれば， 穀物供給地において発生する不作の国際市場に対する 影響は緩和される。そこで, 豰物の国際市場の安定性 を市場の構造特性から検証してみよう。

\section{(2) 市場の統合度と安定性}

国際市場における輸出量の世界総生産量に占的る割 合を国際市場の統合度とすると，統合度の低い市場は， 一般に「薄い市場」之呼ばれ，不安定であると考えら れている。表1は，1975～84年を1期，1982～91年を II期とするそれぞれの期間における国際市場の穀物流 通量の世界全体の生産量に対するシェア，流通量沶よ び市場価格の変動係数を示したあのである。

表1による之，米の流通量シェ了は，I期 $2.8 \%$ ， II 期 $2.6 \%$ で，穀物の中では国際市場の統合度が低い。 しかし, 米の国際市場流通量の変動係数は大きくな 
表 1 .国際市場における穀物の流通量シェアと市場变動

\begin{tabular}{|c|c|c|c|c|c|c|c|c|c|}
\hline \multirow{2}{*}{ 品 目 } & \multicolumn{3}{|c|}{ 流通量シェア } & \multicolumn{2}{|c|}{ 流通量変動係数 } & \multicolumn{2}{|c|}{ 価格変動係数 } & \multicolumn{2}{|c|}{3 ケ国集中度 } \\
\hline & I 期 & II 期 & 1991 & I 期 & II 期 & I 期 & II 期 & 1980 & 1991 \\
\hline 小 & 18.7 & 19.1 & 19.8 & 19.5 & 6.6 & 12.5 & 12.0 & 75.2 & 65.6 \\
\hline 米 & 2.8 & 2.6 & 2.5 & 14.9 & 9.0 & 14.8 & 10.8 & 55.4 & 60.7 \\
\hline 大 麦 & 9.7 & 12.7 & 13.6 & 20.2 & 10.6 & 13.6 & 19.3 & 59.6 & 47.5 \\
\hline トウモロコシ & 17.4 & 13.5 & 13.9 & 13.0 & 8.0 & 11.0 & 9.2 & 87.1 & 85.8 \\
\hline
\end{tabular}

注 : 流通量シェアは世界総生産量のうちの輸出総量の割合 (\%)。流通量変動係数は輸出量变動係数 (\%)。3 ケ国集中 度は上位 3 ケ国の穀物輸出量の世界総輸出量に占めるシェア（\%)，I 期は1975～1984年。II 期は1982～1991年の 期間。

資料：FAO, Trade Yearbook.

い゙．したがって，米の国際市場規模を拡大すると， 国際市場における米の流通量变動を安定化させること を期待させるが, 米は市場統合度が低いから流通量が 変動的であるとはいえない。な㧧通量の変動に対応 した価格变動は, 個々の品目の需要の価格弾性の影響 を受けるので，一義的には断じ難い．

\section{（3）供給集中度と安定性}

1970年代に穀物生産が北米地域に集中した。 Blandorf は少数の国への生産集中は国際市場の穀物
供給を潜在的に危険にすることを指摘している。しか し，供給集中が国際市場を不安定化させているか。

表 1 からは，輸出国集中度の高さが流通量变動係数 を高くしているとはみられない。例えば大麦の 3 ケ国 集中度は低いが，流通量の変動係数は最む高い。また 米は，1991年に対して，3 ケ国集中度で5.3ポイント 上昇しながら, 流通量変動係数が II 期では 5.3 ポイン ト下落している。

表 2。穀物の国際流通シェアと生産・流通量および価格の变動性

\begin{tabular}{|c|c|c|c|c|c|c|}
\hline \multirow{2}{*}{ 輸出地域 } & \multirow{2}{*}{ 主要輸出国 } & \multirow{2}{*}{$\begin{array}{l}\text { 輸 出 } \\
シ ェ ア\end{array}$} & \multicolumn{4}{|c|}{ 変 動 係 数 } \\
\hline & & & 輸出量 & 収 量 & 面 積 & 価 格 \\
\hline \multicolumn{7}{|l|}{ 小麦 } \\
\hline 北米 & USA,CND & 52.3 & 15.0 & 7.0 & 8.8 & 12.2 \\
\hline ヨーロッパ & $\mathrm{F}, \mathrm{G}, \mathrm{UK}$ & 26.3 & 15.8 & 7.3 & 1.7 & 8.5 \\
\hline オセアニア & ASTR & 12.2 & 19.7 & 18.0 & 15.5 & 25.2 \\
\hline 南米 & ARG & 5.9 & 38.4 & 7.0 & 9.0 & 7.9 \\
\hline \multicolumn{7}{|l|}{ 米 } \\
\hline アジア & THL,PKS,VT & 64.5 & 10.8 & 5.8 & 1.7 & 7.0 \\
\hline 北米 : & USA & 19.3 & 11.4 & 6.6 & 7.5 & 9.5 \\
\hline ヨーロッパ & ITL,SPN & 8.7 & 10.4 & 3.7 & 7.7 & 10.1 \\
\hline 南米 & ARG & 4.1 & 10.6 & 9.8 & 9.9 & 9.5 \\
\hline \multicolumn{7}{|l|}{ 大麦 } \\
\hline 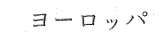 & $\mathrm{F}, \mathrm{G}, \mathrm{UK}$ & 55.6 & 17.7 & 9.3 & 3.8 & 7.8 \\
\hline 北米 & USA,CND & 28.3 & 24.3 & 7.3 & 8.9 & 14.7 \\
\hline オセアニア & ASTR & 12.0 & 52.1 & 6.5 & 16.8 & 25.2 \\
\hline アジア & TRK & 3.3 & 92.4 & 11.8 & 5.5 & 22.9 \\
\hline \multicolumn{7}{|l|}{ とうあるこし } \\
\hline 北米 & USA & 73.0 & 16.7 & 12.1 & 6.3 & 18.1 \\
\hline ヨーロッパ & $\mathrm{F}, \mathrm{BNL}, \mathrm{RMN}$ & 9.4 & 20.7 & 11.0 & 3.8 & 11.4 \\
\hline 南米 & $\mathrm{ARG}$ & 8.9 & 32.0 & 4.1 & 6.3 & 8.5 \\
\hline アフリカ & SAFR & 4.2 & 48.1 & 13.7 & 4.8 & 17.0 \\
\hline アジア & $\mathrm{CHN}$ & 4.0 & 97.8 & 11.0 & 3.6 & 12.8 \\
\hline
\end{tabular}

注 : 収量は ha 当たり収量の変動係数。面積は収穫地面積の変動係数，価格は輸出価格の変動係数でいずれも\%。 計測期間は, 1982 91年。各地域の主要輸出国は, USA:アメリカ合衆国, CND:カナダ, F: フランス, G: ドイッ, UK:イギリス, ASTR:オーストラリア, ARG:アルゼンチン, THL:タイ, PKS:パキスタン, VT: ベトナム, ITL:イタリア, SPN:スペイン, TRK:トルコ, BNL:ベルギーとルクセンブルク, RMN:ルーマ ニア, SAFR:南アフリカ共和国, CHN:中国.

資料: FAO, Trade Yearbook, Production Yearbook. 


\section{（4）生産地特性と安定性}

流通量が安定的であるかどうかは，生産地における 穀物生産の安定性にも依存している，表 2 は，国際市 場に対する主要穀物供給地域の1982 91年の期間にお ける穀物の国際市場流通量シェア, 流通量変動係数, 収量変動係数および収穫地面積変動係数を表したもの である。

どの穀物も国際市場に対して高い輸出シェアを占め る地域の輸出量の変動係数が小さく，低いシェアを持 つ地域の輸出量の変動係数が大きい，地域的には，才 セアニアの小麦・大麦, アジアの大麦・とうあろこし が，生産・輸出とあ不安定である。南米の小麦・米・ とうあろこしの生産はそれほど不安定でないが，輸出 量は変動的である。ヨーロッパは収量が，北米とオセ アニアとは収穫地面積が不安定である。とうあろこし は, 北米とヨーロッパの収量が変動的で, 総生産量, 輸出量が不安定になっている，米は他の穀物より輸出 量も生産量む安定している。しかし，国際的な穀物市 場規模拡大には，供給不安定国の生産拡大が避けられ ない。そこで，国際市場の安定的拡大には，新興輸出 国への技術支援が不可欠になろう。

\section{(5) 流通圈の変化}

自由化による穀物国際市場価格の上昇は，商品間で アンバランスに進行することが予想される。このため, 現在の穀物流通圈が変化するか屯しれない。この場合 あ, 新興輸出国の供給安定対策が必要である ${ }^{4)}$.

\section{4. 国際市場の構造と国内市場対応}

国際市場の変動は，各国市場の衝撃伝達によって発 生し，国際市場結合国の国内市場変動を誘発する ${ }^{5)}$. このため，いくつかの提案がなされている。米の輸入 自由化に関連してその対応について検討しょう。

\section{(1) 国際市場の構造と価格}

まず，外国産米の輸入は業者の自由裁量にまかせる のがよいという考えがある。しかし，この点は国際市 場の競争構造と価格形成の側面からの検討も必要であ る。

国際流通における市場構造の競争形態は，輸出国お よび輸入国における国内・国外市場の穀物取引主体の 数から，以下のような類型区分ができる。

第 1 は, 輸出・輸入両サイドとも各国が独占的需給 者 $^{6)}$ 。第 2 は, 輸出国がすべて独占的供給者で輸入国 がすべて競争的需要者. 第 3 は, 輸出国がすべて競争 的供給者で輸入国がすべて独占的需要者である場合で ある。
（1）輸出国も輸入国も国内では独占体

\begin{tabular}{|c|c|c|c|}
\hline \multirow{2}{*}{ 輸出国 } & \multicolumn{3}{|c|}{ 輸 入 国 } \\
\hline & 1 国 & 少 数 & 多 数 \\
\hline 1 国 & 双方独占 & 制限的供給独占 & 供給独占 \\
\hline 少 数 & 制限的需要独占 & 双方寡占 & 供給寡占 \\
\hline 多数 & 需要独占 & 需要寡占 & 競争 \\
\hline
\end{tabular}

（2）輸出国が独占的供給体で輸入国が競争的輸入体

\begin{tabular}{|c|c|c|c|}
\hline \multirow{2}{*}{ 輸出国 } & \multicolumn{3}{|c|}{ 輸 入 国 } \\
\hline & 1 国 & 少 数 & 多 数 \\
\hline 1 国 & 供給独占 & 供給独占 & 供給独占 \\
\hline 少 数 & 供給寡占 & 供給寡占 & 供給寡占 \\
\hline 多 数 & 競争 & 競争 & 競争 \\
\hline
\end{tabular}

（3）輸出国が競争的供給体で輸入国が独占的輸入体

\begin{tabular}{|c|c|c|c|}
\hline \multirow{2}{*}{ 輸出国 } & \multicolumn{3}{|c|}{ 輸 入 国 } \\
\hline & 1 国 & 少 数 & 多数 \\
\hline 1 国 & 需要独占 & 需要寡占 & 競争 \\
\hline 少数 & 需要独占 & 需要寡占 & 競争 \\
\hline 多数 & 需要独占 & 需要寡占 & 競争 \\
\hline
\end{tabular}

国際流通における穀物の市場構造は，例えば小麦は， 輸出国が少数であるが, 多くの国において輸出は多数 の輸出業者によっている。そして輸入国は多数あるが, ほとんどの国が独占的な国家機関によって輸入してい る . したがって，小麦の国際市場の競争形態は第 3 類型に入り，競争的である。また，米は輸出国が少数 で，ほとんどは独占的機関によって輸出している。一 方，輸入国は多数あるが，輸入は国家機関によってい $る^{8)}$. したがって，米の国際市場は第 1 類型の競争形 態に入り，供給塞占的である。ただしジャポニカ米は 輸入国あ輸出国む少数なので，双方寡占的である。し かし，将来，日本がジャポ二カ米の輸入を民間業者に 制限なしに認めると，輸入需要者多数となって，第 2 類型の供給寡占的形態に移行しょう ${ }^{9}$.

その他の米であ, 輸入国が国内の独占的輸入組織を 解体すると，国際市場における米価形成は第 2 類型の 供給寡占価格の形成条件を持つ。米が供給過剩状態に あるときは，価格形成が競争的になされるが，供給不 足状態になった場合，国際市場における米価形成に独 占的要素が入り込む危険性がある。これに対して，国 内市場では供給独占体となるが，国際市場に対しては， 交渉力を持つ国家貿易形態をとることが期待される。 


\section{（2）上質米生産の限界}

大量の外国産米輸入を控えて, 上質米生産による対 応が考えられている。しかし，上質米生産にあ限界が ある。わが国は玄米換算で年間約 1,050 万トンの米を 消費している。1991年産米について米の種類別数量シェ ア（\%）を推計してみると, 農家飯米15.3, 政府米10.9, 自主流通米 45.6 , 超過米 1.3 , 特別栽培米 0.1 , 特定米 穀4.1, 他用途米4.1, 自由米19.7. 自主流通米之自由 米とを上質米とすると，国内生産米の $65.3 \%$ （約680 万トン）が上質米になる。

表 3 は，自主流通米の大阪入札市場における，1990 年11月の初回落札価格（すなわち指標価格）と1993年 5 月の最終回落札価格との変化をみたものである．価 格ランクは初回落札価格によって区分した。初回から 最終回までにおける価格の変化率は, 価格ランクの高 いあのほど価格下落率が高く, 価格ランクの低いあの ほど価格上昇率が高い。価格のランク別格差は，縮小 に向かっていた。この結果, 初回と最終回の最高ラン ク米の平均価格と最低ランク米の平均価格との範囲は, 大阪の場合，第 1 回では玄米 $60 \mathrm{~kg}$ 当たり 4,752 円の格 差があったが，最終回では1,744円に縮小している。 東京でも同じ傾向にあった ${ }^{10)}$.

表 3 によると, 高価格ランクの上質ブランド米ほど 価格下落率が大きい，上質ブランド米の市場キャパシ ティはかなり狭く, 需要の価格弾性が小さいこと。こ れに対して，低質ブランド米の市場キャパシティはか なり広く，需要価格弾性の大きいことなどがわかる。 したがって, 価格の安い輸入米に対して, 単に上質ブ ランド米を生産拡大してむ, 事態打開は容易でないこ とが推測される。
表 3. 自主流通米のランク別価格

\begin{tabular}{|c|c|c|c|c|}
\hline 価格ランク & 初 回 & 最終回 & 変化率 & $\begin{array}{l}\text { ブラン } \\
\text { ド 数 }\end{array}$ \\
\hline 22,000 以上 & 22,800 & 21,489 & -5.7 & 8 \\
\hline 21,000 & 21,367 & 20,799 & -2.7 & 7 \\
\hline 20,000 & 20,622 & 20,294 & -1.6 & 3 \\
\hline 19,000 & 19,473 & 19,972 & 2.6 & 11 \\
\hline 19,000 末満 & 18,048 & 19,745 & 9.4 & 6 \\
\hline 価格の範囲 & 4,752 & 1,744 & - & - \\
\hline
\end{tabular}

注 : 大阪市場での落札価格 (すなわち指標価格)，玄 米 $60 \mathrm{~kg}$ 当たり円．価格ランクは，1991年11月 の市場落札価格による産地銘柄別区分. 初回は 1991年11月落札平均価格, 最終回は1993年 5 月 の落札平均価格. 変化率は初回価格に対する最 終回価格の変化率 $(\%)$.

\section{（3）異常時に対する政府対応}

わが国政府は米について多方面の管理を行ってい $3^{11)}$. 輸入自由化後, こうした政府管理は不要か. 政 府がこれまでにしなければならなかったことから検討 してみよう。

表 4 は，平年作時の平成 4 米穀年度と不作時の平成 6 米穀年度における政府の米の取扱いシェアをまとめ たあのである。これによると，平年作時の政府取扱い シェアは，集荷19.9\% (不作時1.3\%), 前年在庫持越 87\% (100\%), 総調達供給30.8\% (38.6\%), 需要仕 向28.3\% (38.6\%), 在庫仕向87.5\% (100\%) である. 不作時になると, 政府米は在庫調整, 輸入等のシェア が高まる，異常時において政府の直接管理分野が，米 の確保と在庫調整に向かっていることがわかる。した がって，わが国が米の供給を国際市場に依存する場合， 国際市場が成熟するまでの間，備蓄や輸入などに政府 介入の途を確保しておくことが期待される ${ }^{12)}$.

表 4. 米の豊区と政府米の管理シェア

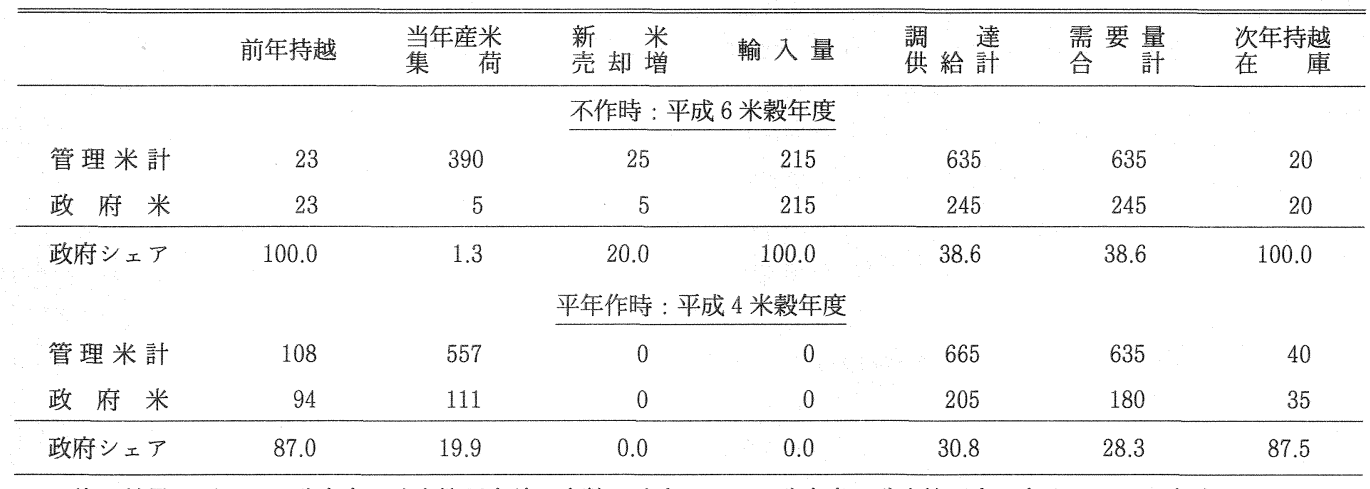

注 : 数量は万トン。政府米は政府管理米計の内数。政府シェアは政府米の政府管理米に占めるシェア $(\%)$. 資料：食糧庁資料。 


\section{5. 要約と結論}

国際的な穀物流通の拡大において，特に問題となる 環境保全, 貿易利益の分配, 安定化の確保, 国内対応 について，国際市場の構造とその特性から論点整理を した。要点は以下のようである。

a）穀物貿易の自由化が農業保護を削減し，直ちに 環境保全を実現するわけではない。また豰物の集中的。 集約的生産が必ずしも農業保護政策のみに依存してい るわけではない，b）自由化がすべての途上国を貧窮 化するわけではない。ただ輸入食糧に依存しなければ ならない途上国のみが自由化の利益分配に与れないだ けである。c）先進工業国の穀物貿易自由化は，穀物 の国際市場規模を拡大するが，供給地域の外延的拡大 を伴う。このため, 国際市場は収量変動や収穫地面積 変動による供給変動要因を抱え込まざるをえない，d） 穀物の国際市場は，現在のところ供給独占体制がこら れていないが，輸入国側の輸入体制によっては供給独 占体制に移行することも予想される。e）本格的な輸 入自由化が始まろうとしているジャポ二カ米に対して は，日本国内の市場キャパシティはそれほど大きくな い. 上質米生産拡大のみの対応では限界がある。有機 米や無農薬栽培米等への多様化が試みられねばならな い.

そこで，款物貿易自由化に対しては，以下のような 対応をとることが示唆される。(1)環境保護は榖物貿易 の自由化によってのみ対応するのでなく，さらに多方 面にわたる環境政策を展開する。(2)食糧純輸入国のう ち，所得水準の低い途上国に対しては食糧生産と食糧 援助をする。(3)国際市場拡大に応じて穀物生産を拡大 する地域に対して，穀物生産および環境保全に関する 技術援助をする。(4)国際市場安定化のため，穀物輸入 国は備蓄体制を強化する。(5)供給独占市場形成を阻止 するため，穀物市場取引に対する輸入国の市場交渉力 の保持。このため，国家貿易ルートを保留しておく。 特に備蓄は，翰出国における備蓄意欲の低下や途上国 における多国籍機関による備蓄計画規模が低下傾向に ある現在 (Blandorf)，国際市場安定のため，市場が 成熟に至るまでの間, 輸入国による国家備蓄が重要で ある。

以上のような国際流通過程や輸入国市場のみならず, 輸出国市場や安全性問題をも含む穀物の商品特性など の分析すすでにわが国で始まっている ${ }^{13)}$ 、いずれも国 際流通研究の桪開に欠かせない研究課題である。
注1）どれだけの環境政策が実施できるかは，環境保全技術 の存在のほかに国民の環境需要欲求がある。国民の環 境需要は所得水準とともに高まるとされている。

2）食用穀物に対する需要の価格弾性は，高所得国で低く， 低所得国で高い，例えばジャポニカ米の需要洒格弾性 は，日本一 -0.10 , 韓国一 0.15 , 台湾一 0.25 である (Cramer) ,

3）ただし，市場の変動係数は計測期間によって異なる。 例えば，計測期間を短縮して1976〜80年（あるいは87 〜91年）にすると,輸出量の変動係数(\%)は, 小麦 12.9 (5.2), 米14.8 (9.1),大麦7.8 (3.3), とうあろこし 12.5 (6.8) となる.

4) 世界の穀物流通をマトリックス表示すると, 北米・ア ジア流通圈。 $\mathrm{E} C$ 域内流通圈, 北米・アフリカおよび 中東流通圈, 北米・南米流通圈，というょうな豰物流 通の地域的分化がみられる。例えば米は，夕イが中東 およびアジア諸国に，アメリカが南米，中東打よびE C諸国に供給している。南米域内ではさらにウルグア イ，EC域内ではイタリアからの供給がおこな利て いる。

Cramer は，自由貿易下では高品位インディカ米よ りジャポニカ米の価格が高くなり，インディカ米より ジャポニカ米の輸出量が増加すること, 輸出米をイン ディカ米からジャポニカ米に転換する国の出ることを 予測している。

5) 例えば米の輸入自由化によって，日本はジャポ二力米 490 万トン，高品位インディカ米248万トン，低品位イ ンディカ米72万トン，合計 810 万トンの外国産米を輸 入するであろうとCramer 等は予測している。また森 島等は，短期で 665 万トン，長期で 876 万トンの米の輸 入を予測している，仮に 800 万トンの米を輸入すると したら, 需要量が1,050万トンにとどまっても，国内 産米は250万トン（国内需要の $23.8 \%$ ) で足りること になる。

6 ) 表中の制限的供給独占, 制限的需要独占は, H. Moeller, Kalkulation, Absatzpolitik und Preisldung, Wien, 1941 の市場型分類による (Gutenberg).

7）1980～84年における小麦の国際市場構造は，輸出国で $66 \%$ が民間業者，34\%が国家機関。輸入国では 4\%が 民間業者，96\%が国家機関であった (Thursby).

8) 主要国の米の輸出入機関は以下のようである (田中)。 韓国: OSROK (韓国物資調達庁)。台湾: 経済部国際 貿易局. 中国: 対外貿易部糧油食品進出口総公司。夕 イ: 米輸出業組合. ミャンマー: MEIC（ミャンマー 輸出入公司)。インドネシア: BULOG (食糧調達庁)。 アメリカ合衆国: 精米業者32社 (RMA (全米精米業 者組合）に加盟）。ただしアメリカの米の輸出構造は, 少数の精米業者が大きなシェアを持つ嚊占構造になっ ている(过井)。ブラジル: 業者。オーストラリア： Rice Growers' Co-Operative Mills Ltd (米生産者組 合精米会社)。イタリア: Ente Nationale Risi（全国 米公団).

9) 日本の米の輸入業務は現在 22 の登録商社によって行わ 
れている。各社の輸入国数は以下のようである。伊藤 忠商事(7)，兼松(7)，金商又一(7)，丸紅(7)，三菱商事 $(7)$, 三井物産(7)，二チメン(7)，日商岩井(7)，住友商事(7)， 東食(7)，トーメン(7)，金商又一(5)，明和産業(3)，野村 貿易(3)，加藤商会(2)，野崎産業(2)，大洋物産(2)，東光 物産(2)，東京貿易(2)，ユアサ商事(2)，住金物産(1)，野 村貿易(1)，東京丸一商事(1)，和光交易(1)。商社の輸入 業務は地域別に限定されている。例えば夕イからは12 社, ミャンマーからは10社, アメリカからは10社, 中 国からは13社が輸入できるようになっている。登録商 社の新規参入は食糧庁から認可されていない（朝日新 聞，1993年10月15日および1994年 4 月25日)。

10）その他の米です低価格米ほど価格上昇率が高かった。 1989年以降92年までの間における米の種類別価格の変 化をみる之，自主流通米は $0.1 \%$ 上昇，自由米 $2.3 \%$ 上 昇, 政府米は $2.2 \%$ 下落, 特定米穀 (米粉用: 販壳業者 の実需者販売価格）は $59.4 \%$ 上昇，くず米(うるち) は $86.7 \%$ 上昇, くず米（あち）は $157.8 \%$ 上昇してい る。

11）政府の米の主要管理業務は以下のようである。生産管 理 : 使用農薬の制限, 米生産者登録, 米の生産調整; 流通経路管理: 米の輸入（独占的輸入）/数量制限, 配給 (独占的供給), 米の生産・販売の規制, 集荷業 者の指定, 卸壳業者の指定, 小壳業者の許可（数の制 限と資格制限），卸・小売の関係の制限（結びっきの 維持), 卸・小売業務の制限／営業範囲の制限; 商品 管理: 規格設定と米の検查・等級付け, 残留農薬検査, 表示の規制, 米の原料構成の規制, 米の販壳形態の制 限 (小袋販売, ブレンド販売，セット販売等）。米の 在庫管理（備蓄）；価格管理：政府米の生産者買上げ 価格・卸売業者への売渡し洒格の決定，自主流通米価 格形成の指導，自主流通米入札価格形成の管理，標準 価格米の原料構成之価格設定の指導。

12）米価安定のための政府介入は，十分な所得が得られる かぎり不要である。1991年現在，日本の家計の食料費 シェアは $27.4 \%$ ，米の購入費シェアは $1.6 \%$ にすぎな い。こうした状況での米価変動は国民の消費生活にほ とんど影響を及涅さない（吉田'94）。

13）例えば, 加賀爪, 亀谷, 辻井, 森井, 森島, 山田, 吉 田，その他多くの研究成果がある。

$$
\text { 引用文献 }
$$

加賀爪優『食糧・資源輸出之経済発展』大明堂, 1993 . 亀谷是・堀田忠夫編著『米産業の国際比較』養賢堂, 1991. 田中 勉監修『米穀の流通之管理』地球社, 1985 。
辻井 博『世界コメ戦争』家の光協会, 1988 ,

森井淳吉「世界米市場をめぐる諸問題」（柏尾昌哉他監修 『国際流通とマーケティング』同文館)，pp. 145-165, 1992.

森島賢監修『コメ輸入自由化の影響予測』富民協会, 1991 . 山田達夫『日本の食糧・日本の農業』シーアンドシー企画・ 労衔旬報社, 1992 .

吉田十一「自由貿易と農産物価格政策」，頼平編『国際化時 代の農業経済学』富民協会, 1992, pp. 31-47.

Anderson, K. and R. Tyers, "More on Welfare Gains to Developing Countries From Liberalizing World Food Trade," Journal of Agricultural Econmics, Vol. 44, No. 3, May' 1993, pp. 189-204.

Antle, J.M., "Environment, Development, and Trade between High and Low-Income Countries," American Journal of Agricultural Ecomomics, Vol.75, No.3, August 1993, pp.784-788.

Blandorf, D., "Instability in World Grain Markets", Journal of Agricultural Economics, Vol.34, No.3, September 1983, pp.379-395.

Chishti, A.F., Liberalization of Pakistans Basmati Rice Trade: Would it Cost to Pakistan?, Contributed Paper to the First Asian Conference of International Agricultural Economists, August, 1993.

Cramer, G., E.J. Wailes, an S. Shui, "Impacts of Liberalizing Trade in the World Rice Market," American Journal of Agricultural Economics, Vol.75, No.1, February 1993, pp.219-226.

Gutenberg, E., Grundlagen der Betriebeswirtschaftslehre, Bd. II. Der Absatz, Springer-Verlag, Berlin, 1956 (溝口 一雄, 高田 馨訳『経営経済学原理, 第 2 巻, 販売論』, 干倉書房, 1958)。

Parris, K. and J. Melanie, "Japan's Agriculture and Environmental Policies: Time to Change," Agriculture and Resources Quarterly, Vol.5, No.3, September 1993, pp.386-399.

Thursby. M.C., "Strategic Models, Market Structure, and State Trading: An Application to Agriculture," in R.E. Baldwin (eds.), Trade Policy Issues and Empirical Analysis, Chicago: University of Chicago Press, 1988.

Yoshida, J., "Japan's Economic Problems of Rice, 1993 94," Science Reports of Shiga Prefectural Junior College, No.46, September 1994, pp.49-56.

(筆者：滋賀県立短期大学） 